\title{
Antivilo, Julia (2015). Entre lo sagrado y lo profano se tejen rebeldías. Arte Feminista nuestroamericano. Bogotá: desde abajo. 239 p.
}

\section{Stella Salinero \\ Investigadora independiente, Red Chilena de Violencia contra las Mujeres \\ stellasalinero@gmail.com}

Este libro de la historiadora y artivista feminista Julia Antivilo (1974) no es solo un gran trabajo de sistematización de una larga trayectoria de arte feminista en nuestra América, sino que, al mismo tiempo, constituye un aporte de gran valor en un campo de estudio que va adquiriendo cada vez más relevancia.

Su escritura ha significado, para la autora, visitar muchos países de la región; reunirse con numerosas artistas, críticas e historiadoras; escarbar en los archivos y contribuir a reactivarlos; reanudar historias e internarse en lo que está pasando en el ambiente artístico contemporáneo. Julia Antivilo está implicada con su escritura, comprometida con su quehacer, y ello se percibe claramente en el estilo del libro, narrado durante largos pasajes en primera persona. Es por eso que, en esta lectura, también vamos conociendo su propia práctica. Este es un punto muy relevante, pues, gracias a la calidez del texto, a su estilo cercano, resulta fácil acercarse a la teoría. Leer este libro es sentir que estamos frente a alguien que nos cuenta una historia que es necesario conocer y difundir: la de la resistencia y lucha de las mujeres desde la particular trinchera que es el arte feminista.

La autora nos va internando en el entramado de la práctica artística feminista latinoamericana, en sus principales problemáticas, formas de expresión, estrategias, afanes y vicisitudes. Colectivas y artistas toman cuerpo en este libro y con gran fluidez recorremos cuarenta años de historia del arte feminista. La autora nos aclara que no sólo se ocupó de estudiar y analizar las prácticas de artistas que se definen como feministas, sino que, asimismo, de activistas y "artivistas" (conjunción que permite agrupar a quienes hacen activismo, arte y archivo).

Muchas de las artistas y colectivas incluidas en este relato, tales como Ana Mendieta, Monique Altschul, Cecilia Vicuña, Elizabeth Neira, Mónica Mayer, Maris Bustamante, María Luisa Bemberg, Nadia Granados, las colectivas Zunga, Mujeres creando, Lobas Furiosas, Mujeres públicas, Tlacuilas y Retrateras, entre otras, hacen un arte decididamente, comprometido con el proyecto feminista (aún cuando

\footnotetext{
* Recibido: 5 de agosto de 2016 / Aceptado: 8 de septiembre de 2016.
}

Leído en el lanzamiento del libro en la Sala Musicámara de la Universidad de Valparaíso el miércoles 27 de julio de 2016. 
reconocemos que hay diferentes perspectivas dentro del movimiento, nos interesa exponerlo como una tradición que las agrupa en un proyecto común de emancipación). El arte feminista se caracteriza, para Antivilo, por ser disidente, subversivo, transdisciplinar. Para la autora, sus trabajos deben ser leídos desde las teorías feministas y se insertan en esta tradición en la medida en que contribuyen a criticar prácticas coercitivas o a cuestionar los mandatos de rol de género asignado a las mujeres. Se trata, la mayor parte de las veces, de mujeres que utilizan el arte para rebelarse contra las condiciones de vida a las que se les quiere condenar socialmente. De este modo, las prácticas descritas están al mismo tiempo dentro y fuera del campo del arte o, dicho de otro modo, se trata de obras que transitan de manera fluida en una dimensión que tiene como ejes la militancia política y la producción artística.

Para quienes nos hemos dedicado al estudio, el análisis y la difusión de la práctica artística feminista o a realizar lecturas feministas de la práctica artística de mujeres, este texto nos Ilega como un viento fresco que viene a renovar el ambiente. Libros como éste son difíciles de encontrar, no sólo porque aún hoy hay una carencia de investigadoras e investigadores sobre el tema (o por lo menos en nuestro país la producción es mas bien incipiente), sino y sobre todo, porque se topan con un ambiente editorial poco receptivo, que ignora deliberadamente este tipo de producción crítica, ya sea porque resulta incómoda para el modelo hegemónico o porque simplemente no es comercializable. Este tipo de libros contribuye a crear una audiencia y nos permite encontrarnos para sentirnos parte de una tradición.

Pero este libro también tiene mérito al recuperar, para nuestra memoria, autoras, colectivas y obras que son propias del acervo cultural de las mujeres latinoamericanas. Hace entrar, en los libros de historia del arte, obras, acciones y nombres de mujeres que de otro modo seguirían condenadas al olvido. Y lo hace mostrando su enorme valor, al oponerse a los estereotipos sexuales mediante la exploración de la sexualidad y el cuerpo, la crítica de figuras míticas como la de "la madre" o "la virgen" o, más directamente, la oposición a la violencia de género a la que nuestra sociedad parece tan acostumbrada.

Resulta sumamente interesante observar las estrategias utilizadas por las artistas de diferentes lugares de Latinoamérica para enfrentarse a la violencia real o simbólica que se dirige contra nosotras constantemente. Un aspecto central de las prácticas feministas ha sido el uso del humor, la ironía, la parodia o el sarcasmo, como, por ejemplo, en el contradesfile realizado por Jesusa Rodríguez y organizaciones feministas titulado Miss Realidades, pasarela de las más aborrecidas, en paralelo al desarrollo del concurso Miss Universo; o el provocador video Maternidad obligatoria, de Nadia Granados, La Fulminante, en el que juega con un condón usado, expresando una sexualidad femenina gozadora y empoderada, 
que se yergue contra el discurso de la iglesia que une coito con reproducción. Se trata de estrategias que permiten decir(se) atravesando los excesivos controles normativos que se nos imponen a las mujeres en las sociedades machistas.

El libro nos permite conocer interesantes y exitosas experiencias de colectivas artísticas que elaboraron estrategias para llegar a la mayor cantidad de gente posible, para construir audiencias y, con este objetivo, acceder a medios de comunicación de masas como la televisión. En este caso, fueron paradigmáticas las obras de las colectivas Polvo de gallina negra, de México, o Mujeres creando, de Bolivia, porque, como nos deja en claro Antivilo a lo largo del libro, a la práctica feminista en Latinoamérica le interesa llegar a la mayor cantidad de gente posible, con el fin de interrumpir, criticar o socavar los imaginarios que constriñen a las mujeres y desde allí contribuir a crear nuevos imaginarios. Gracias a acciones como éstas, las prácticas se hacen presente en la vida cotidiana y, con ello, van también expandiendo los límites de lo que se entiende por arte u objeto del arte. Se trata de una suerte de democratización o liberación del arte, que pasa a ser también una estrategia expresiva al alcance de muchas; una estrategia que permite conectar en un lenguaje común distanciado del canon impuesto por la academia (que sabemos posee los mismos sesgos que anidan en nuestra sociedad).

El libro se dedica a analizar particularmente en profundidad una práctica artística: la performance. Se la localiza como un espacio central de la práctica feminista de nuestra región, principalmente por su estrecha relación con el cuerpo y la experiencia personal (que tanto valor toma para la política feminista como un lugar de referencia legítima). La performance es un modo de "poner el cuerpo" en la política feminista que desarrollan las artistas. Desde conferencias performanceadas, pasando por la performance como una forma de ritual de sanación colectiva, hasta enterderla como una pedagogía feminista, ésta práctica se perfila como una de las maneras más efectivas para acceder a la corporalidad e intervenir en la realidad social. Resulta interesante destacar que la discusión en torno al concepto de performance ha emanado desde las propias artistas que circulan por el texto, principalmente a partir del trabajo de Mónica Mayer.

Otro punto importante que quisiera destacar se refiere al uso que hacen las artistas de la llamada "cultura popular". Específicamente, en la apropiación crítica de tradiciones que marcan las experiencias de las mujeres, por nombrar un ejemplo, la parodia de la fiesta de los quince años en México realizada por la colectiva Tlacuilas y Retrateras o el llamado a concurso de Mujeres creando para inventar la imagen femenina del Ekeko. Para Julia Antivilo, estos son casos de apropiación "profunda y sentida", cuyo fin último es proveer tales tradiciones de otros significados. La práctica feminista se nutre de la cultura popular desde una óptica que subvierte sus significados y le permite apropiárselos de un modo novedoso. Lo popular es rescatado y revalorado, toda vez que resignificado creativamente para 
su uso actual y crítico. Es interesante, como bien nos recuerda Antivilo, que el movimiento feminista -desde sus orígenes- ha hecho suya la capacidad creativa y la ha utilizado sistemáticamente como un arma crítica. En este sentido, su política ha ido siempre de la mano de una estética propia. Lo anterior resulta relevante, pues, desde el sistema del arte, la creatividad ha sido considerada desde siempre como una prerrogativa masculina, como si los hombres fuesen los únicos detentadores del poder de creación y producción.

Como afirmé al comienzo, la autora está implicada tanto teórica como prácticamente en este libro. Nos cuenta una historia que también es su historia, como, por ejemplo, la de su participación en diversas colectivas. Entre ellas, destaca Malignas Influencias (2004-2009), con la que exploró cómo, aún en nuestros días, operan sobre y en nuestros cuerpos y mentes ciertas prótesis de censura heredadas de la colonia, cuyo fin último fue (y sigue siendo) disciplinar el cuerpo de las mujeres, transformarlos en cuerpos de y para otros. Este libro tiene el mérito de permitirnos reconocernos y sentirnos parte de algo más grande, la historia del movimiento de lucha por la emancipación de las mujeres. Nos hace sentirnos solidarias/os de otras luchas equivalentes y complejiza el cuadro mostrando cómo otras categorías históricamente consideradas "subsidiarias" resultan fundamentales en la política y el activismo feminista contemporáneo: la clase, la etnia, la fluidez sexual (entendida como la negación a estar dentro de categorías dicotómicas), etc.

Se trata de un libro envolvente, de una escritura empoderada que no tiene pudor a la hora de usar la primera persona, ya que nos habla desde su propia experiencia. En este sentido, es un libro íntimo, una historia íntima del arte feminista nuestro-americano. Como lectora, siento que leerlo ha sido una experiencia y que me ha implicado corporalmente. La lectura se va esparciendo literalmente por todo el cuerpo. Se nos van desatando de forma progresiva múltiples emociones. Una multiplicidad de recuerdos concurren al avanzar por sus páginas: las imágenes, sensaciones y sonidos de nuestras propias prácticas de activismo (por ejemplo, la campaña de la Red chilena contra la violencia hacia las mujeres, la caminata del silencio, el tambor de la Revolución del caldero, las intervenciones callejeras de la colectiva Lupitas del Sur, entre otras). Hay también, en estas páginas, numerosos temas cercanos que nos interpelan y nos hacen reflexionar sobre nuestras propias prácticas cotidianas: la casa, el placer, la maternidad, la menstruación, la crianza, entre otros.

Entre lo sagrado y profano, este libro nos permite revisar los dispositivos de control instaurados desde la colonia y sostenidos, muchos de ellos, hasta nuestros días. Pero también nos permite entrever las formas de burlar dichos dispositivos, de reapropiarnos sus signos con fines de lucha y transformación. Resulta paradigmática la reapropiación crítica de la imagen de la Virgen. Como sabemos, la virgen 
es el modelo femenino por excelencia de pureza y castidad, abnegación y resignación. En las páginas de este libro podemos ver cómo las artistas convierten a la Virgen en su aliada, al alzarla como ícono feminista, al despojarla de su sacralidad, al profanar su sentido original, como es el caso de la colectiva Mujeres públicas, entre otras.

No puedo dejar de agradecer el gesto de Julia que se ha decidido resueltamente a dialogar con autoras y autores latinoamericanos. Se trata de uno de los pocos libros de historia del arte en que abundan los nombres propios, latinos o lusos, y en que nos quedamos con una experiencia cercana. Autoras y autores que se nos asemejan, que viven en contextos que son los nuestros, que realizan sus trabajos con las mismas limitaciones que nosotras.

Para terminar, quisiera destacar que la autora también concibió su libro como "un collage artivista y archivista". Con este cometido es que nos entrega un largo listado con información sobre artistas y colectivas, sus países de origen y las disciplinas a la que se dedican. Se trata de una interesante invitación a conocer e investigar, a seguir contribuyendo a crear nuevas lecturas de la práctica feminista; lecturas que nos abran nuevos caminos, porque el feminismo siempre ha sido una invitación, un puente donde caben todas y todos quienes luchan por un mundo más justo. Parafraseando a Gabriela Mistral, diría que este libro es una albricia, ya que se trata de un regalo, una sorpresa de esas que algunas veces nos encontramos en el camino. 